\title{
DEMAND DRIVERS OF FEMALE LABOR FORCE PARTICIPATION: EVIDENCE FROM SELECTED AFRICAN COUNTRIES
}

\author{
Omowumi O. Idowu ${ }^{1}$ \\ date of paper receipt: \\ 04.04.2019. \\ Review Article \\ date of sending to review: \\ 08.04.2019. \\ doi: 10.2478/eoik-2019-0007 \\ date of review receipt: \\ 16.04.2019. \\ UDK: 339.923:331.102.12(6) \\ ${ }^{1}$ Department of Economics, Ekiti State University, Ado-Ekiti, Ekiti State, Nigeria
}

\begin{abstract}
This study investigates the demand drivers of female labor participation in a panel of twenty (20) selected African countries across five sub-regional groupings (West Africa, East Africa, North Africa, Central Africa and South Africa), over the period 1990-2015. The study sourced data from World Bank Data Bank. Poverty and gender inequality in employment were used and measured respectively by life expectancy at birth and gender ratio in labor participation. Other variables included are wage rates, female marginal labor productivity and household income. Autoregressive Distributive Lags (ARDL) procedure of dynamic panel model was used. The result from the Dynamic Fixed Effect (DFE) revealed that female marginal productivity of labor and gender inequality in employment have a significant positive impact on demand for female labor in the long run, however female marginal productivity was found negative in the short run. It is therefore important that, in order to bridge the gender gap in employment, government should ensure gender sensitive policies and remove all forms of institutional barriers to female labor demand. Efforts should also be made to improve female productivity through training, literacy and household food security. In order for female demand to meet desired response, adequate support services and provisions that can entice female to work outside home should be provided.
\end{abstract}

Keywords:

Labor; Demand; Female Labor; Participation

JEL: J23, J16, J21 


\section{INTRODUCTION}

This study examines the pull and push demand determinants of female labor force participation in Africa using a panel data between 1990 and 2015. Countries were chosen based on the ranking of the Population Reference Bureau (2015) of gender ratio of female labor force participation in Africa. The highest, lowest and the closest to the middle of gender ratio of labor force participation rate were selected. Gender ratio of labor force participation is central to this study as it gives a good representation of female labor force participation in each region in Africa (either it has lowest, highest or average gender representation in Africa). The UN World Population Prospect (2015) 2 was used to select the countries with highest population across African regions. The data covers 20 countries chosen across five African sub-regions to capture diverse economic and social characteristics across Africa. .

The increasing participation of women in economic activitiescreates a multiplier effect on productivity, efficiency and sustained economic growth (United Nations, 2008)3. This is because when women earn income, it is invested in thewellbeing of their children, including educating them and improving their health conditions (Ernst and Young, 2011) ${ }^{4}$. Women usually reinvest a much greater part of their earnings in their families and communities than men thereby spreading wealth and creating a positive impact on future development (World Bank, 2009)5. Evidence show that in Bangladesh, Brazil, Kenya and South Africa among other countries, children welfare in poor households (including nutritional status and schooling attendance) improves better when income is in women 's possession rather than men's (Ernst and Young, 2011)6. In addition to this, a study conducted by World Bank in 2011, discovered that the probability of a child surviving increases by about 20 percent when income is in the hands of the women, because women invest more of their income in health and nutrition. Therefore, creating opportunities for women in the economy, particularly in developing economies will improve their earning capacity, serves a spring board for families to move out of poverty and, contributes greatly to the overall economy. Sachs (2009)7 also argued that embracing gender equality through increased women participation in labor market will facilitate growth and raise the overall level of human capital, productivity and wages. This may be responsible for the new trend in international and local programmes / policies to improve female participation. For example, the affirmative call for 35\% women participation in economic formal activities.

The effect of change in female labor participation has been differently felt in Africa depending on their level of development and social settings. For example, according to the World Population Reference Bureau (2015)8, the gender ratio of labor force participation is 0.76 in West Africa, 0.92 in East Africa, 0.90 in Central Africa, 0.75 in South Africa and 0.32 in North Africa. However, the demand for female labor force participation in Africa is influenced by gender inequality in employment, and low GDP growth rate (due to weak and inappropriate macroeconomic policies and reforms), demographic change and low labor productivity (Morikawa, 2015)9. Also, private sector job creation in Africa was too weak to absorb the fast-growing labor force. Gender disparities in employment may serve as a push factor for a country to encourage female labor force participation, thereby bridging the gap in employment between male and female.) This will provide the impetus for growth and increase the overall level of human capital, productivity and wages (Sachs, 2009)10. Invariably, there exists a positive relationship between demand for female labor force participation and gender inequality, particularly, in employment. As gender inequality persists in employment, government as part of its efforts to bridge this gap may demand and encourage more female participation in the economy.

The demand for female labor force participation can be driven by poverty which also serves as a push factor, while female's economic productivity is an important factor, as the dependence of the family on their contribution to household resources increases with the poverty status of the household (Mahapatra, 2002)11. The study by Klassen and Pieters (2012)12 indicate that 
female labor participation is driven by necessity rather than economic opportunities and that the economic participation of women is mainly determined by economic push factors and social status effects. Increase in income and economic participation of women provide the spring board for the alleviation of poverty in the family and the economy as a whole (World Bank 200913; Ernst and Young, 201114). Therefore, based on the analysis above, there exist a direct relationship between poverty and the demand for female labor force participation.

There is a paucity of studies on concerning the demand determinants of female labor participation in Africa. Some of the studies that attempted to address this issue include Bernal and Cardenas (2003)15, Plekutowska (2007)16, Rotaru (2013)17 and Maleszyk (2014)18. The demand side of female labor force is important in this study in order to know the effect of some socio-economic indicators, which might not be captured on the supply side. This study is also important because of the changing nature of global economy where manufacturing entities are shifting to developing countries because of cheap labor. A better understanding of how this shift affects the demand for female labor participation is important. This study contributes to existing literature in a number of ways. First, it concentrates on data from Africa where scholars have rarely examined the determinants of female labor participation. Two, it looks at the demand side of female labor participation disaggregating it to push and pull factors, and then uses the dynamic fixed effect to examine the relationship among the variables. Finally, by selecting countries across all the five African sub-regions (Northern, Central, Southern, Eastern and Western Africa), this study covers diverse sub-regions in Africa.

The rest of this paper is organized as follows: section two reviews and discusses the related literature. Section three presents the methodology, while section four presents estimation, analysis of result and discussion. Section five deals with summary, conclusion and policy recommendations.

\section{LITERATURE REVIEW}

Limited studies exist on the demand side determinants of labor as studies examine labor demand from firm's perspective. Example of such studies is Ibrahim (2013)19 who used annual time series cross sectional data from 1990 to 2007 and fixed effect panel seemingly unrelated regression. The study estimates the factors responsible for private sector labor demand for employment in Egypt. A positive relationship between private demand for labor employment and real private domestic products was found, while a negative relationship was found with real wage in the long run. Nguyen (2013)20 examined the effect of firm ownership on labor demand in Vietnamese manufacturing between 2000 and 2009. The study used firm level data and discovered that labor demand of domestic firms and foreign invested enterprises responded slowly to wage changes while joint ventures have greater employment elasticity with respect to output, compared to domestic firms. Using panel data sourced from EU KLEMS database involving observations between 1970 and 2007 for twenty three industries across eleven European area countries. Adam and Moutos (2014)21 provided industry by industry estimate of the labor demand function. The result indicated that decreases in wage have a future effect on employment growth.

On macro studies, Bernal and Cardenas (2003)22 used quarterly data from urban household survey and full information maximum likelihood procedure to investigate the determinants of labor demand in Columbia. The study discovered that structural reforms such as adjustment cost of changing employment and wage elasticities did have an impact on labor demand through its effect on relative prices only. In investigating the labor demand determinants for immigrants in Poland, Plekutowska (2007)23, the study emphasized the prevalent of unemployment in Poland which normally should make the demand for labor easier. However, structural mismatch of demand and supply of domestic labor constitutes a significant factor for foreign labor demand. In 2013, Rotaru developed a model that describes the relationship between the employment rate of labor resources and other labor related socio economic factors, in Romania. The model was estimated 
using time series data from the Romanian National Institute of Statistics. The outcome of the analysis showed that household income has a positive impact on labor employment. However, labor marginal productivity negatively impact labor employment. Moreover, Ibrahim (2013)24 empirically investigated the determinants of labor demand in Egypt using annual time series cross sectional data between 1990 and 2007. The study used fixed effects panel seeming unrelated regression model. It discovered that there was a significant positive relationship between private demand for labor and real private domestic product, private investment and real wage. However, in the short run real wage was found to be insignificantly negative.

Also, different factors could be responsible for macro and firm level evidence on the demand for female labor participation and these differences will affect the determinants at the two levels. In most cases, entrenched traditions like patriarchy ideology and gender roles and expectations, usually encourage low female economic participation. Notwithstanding most countries sometimes attempt to implement policies that will increase female employment. On one hand, factors such as GDP growth, wages and female marginal productivity of labor may serve as incentive to increase female labor demand in a country. On the other hand, household income, inequality in employment and poverty may propel (push factors) a country's demand for female labor.

\section{METHODOLOGY}

In line with the classical theory of labor demand $\mathrm{ddFLFP}=\mathrm{f}$ (GDPgr, Wages, Marginal Labor Productivity)

In context of this study some other variables that could be responsible for female labor demand at country level were added. These are household income, inequality and poverty.

Therefore, in functional term, ddFLFP = f (GDPgr, Wages, Female Marginal Labor Productivity, GDP per capita, Inequality, Poverty) -

Demand for female labor force was proxied by the percentage of the female population that is employed out of the total female population.

This was calculated thus; $\mathrm{x} 100$

Where GDP growth rate is the change in total output produced in a country from one period of time (usually a year) to the next, which according to the classical theory of labor increases as labor demand increases. Wages was measured using compensation of employees (\% of expense). This consists of all payments in cash, as well as in kind (such as food and housing), to employees in return for services rendered, and government contributions to social insurance schemes such as social security and pensions that provide benefits to employees. Female marginal labor productivity is derived by dividing GDP growth rate by change in total number of female employed. According to the classical theory, there is a negative relationship between labor marginal productivity and demand for labor, such that the marginal productivity of female labor declines as more female labor is employed due to diminishing marginal returns (Samuelson, 2003)25. GDP per capita is used as a proxy for household income. This is GDP divided by the midyear population and it is otherwise known as income per head. Inequality was measured using gender inequality in employment, proxied by the gender ratio in labor force participation. A ratio less than one indicates that the male labor force participation rate is greater than the female rate while a ratio of more than one indicates that the female rate is greater than the male rate. Gender disparities in employment may serve as a push factor for a country to encourage female labor force participation, thereby bridging the gap in employment between male and female. This will provide the impetus for growth and increase the overall level of human capital, productivity and wages (Sachs, 2009)26. Invariably, there exists a positive relationship between demand for female labor force participation and gender inequality, particularly, in employment. As gender inequality persists in employment, government as part of its efforts to bridge this gap may demand and encourage more female participation in the economy. 
Poverty was measured using Human Poverty index; life expectancy at birth as a proxy for longevity According to the report on poverty in sub-Saharan countries, the human poverty index is a composite index based on three important aspects of human deprivation, which are longevity measured by the probability at birth of not surviving to age 40 , knowledge measure by adult literacy and a decent standard of living measured by percentage of people without access to safe water, percentage of children underweight under age 5 (Statistical, Economic and Social Research and Training Centre for Islamic Countries, 2007)27. The prevalence of poverty in a country may constitute a push effect for such country to improve its labor participation, particularly female participation based on the fact that this creates a multiplier effect on production, efficiency and thereby leads to sustainable growth (United Nations, 2008)28. Increase in income and economic participation of women provides the spring board for the alleviation of poverty in the family and the economy as a whole (World Bank 2009; Ernst and Young, 2011). Therefore, based on the analysis above, there exist a direct relationship between poverty and the demand for female labor force participation

The model is thus specified;

$\mathrm{ddFLFPi}, \mathrm{t}=\alpha 0+\alpha 1$ GDPgri, $t+\alpha 2$ CEgri, $t+\alpha 3 \mathrm{FMPi}, \mathrm{t}+\alpha 4 \mathrm{GDP} / \mathrm{pi}, \mathrm{t}+\alpha 5 \mathrm{GRPi}, \mathrm{t}+$ $\alpha 6 L E B i, t+\mu \mathrm{i}, \mathrm{t}$.

Where:

ddFLFP - Demand for Female Labor Participation

GDPgr - Gross Domestic Product (growth rate)

CE - Compensation of Employees

FMP - Female Marginal Labor Productivity

GDP/p - Gross Domestic Product per capita

GRP - Gender Ratio in Labor Force Participation

LEB -Life Expectancy at Birth

$\mu$ it - Error term

\section{DATA ANALYSIS}

\subsection{DEVELOPMENT AND TREND OF DEMAND FOR FEMALE (\% OF TOTAL POPULATION) LABOR FORCE PARTICIPATION IN THE SELECTED AFRICAN COUNTRIES}

The trend analysis of female labor demand proxied by the percentage of female population that is employed depicted in fig 1, shows that Togo has the highest female demand of 75.2 percent of its female population in West Africa. It has been experiencing an upward trend from 1991 (62.4 percent) to 2015 (75.2 percent).

Agriculture is the mainstay of Togo's economy and this employ close to four fifth (4/5) of the active population including women. Agrarian economy is basically dominated by women because it is cheap for any economy to employ women than men, hence the high demand for female labor in Togo. This is followed by Ghana with a downward trend, though unstable from 1991 to 2008, but from 2009 it has been increasing with its highest of 71.2 percent in 2014. Nigeria was found below 50 percent at its peak in 2015 with 46.0 percent.

Inspite of considerable high level of female literacy, cultural influence and patriarchal ideology of what is expected of a man and a woman dictate the role a woman can play in the economy, hence Nigerian women are discriminated against in employment opportunities and decision making positions. Meanwhile Mauritania was with the lowest female labor demand in West Africa; at its peak in 2014 with 25.6 percent of its female population. In Mauritania women remain minors as existing laws strictly discriminate against female child (according to family code 'code du statut personnel'). Although, Mauritania legislation provides for equal rights with respect to employment, but no specific measure has been taken to eliminate discrimination against women in education, 
employment and labor participation.

Figure 1. Trend Analysis of Demand for Female (\% of total Population) Labor Force Participation in the selected African Countries

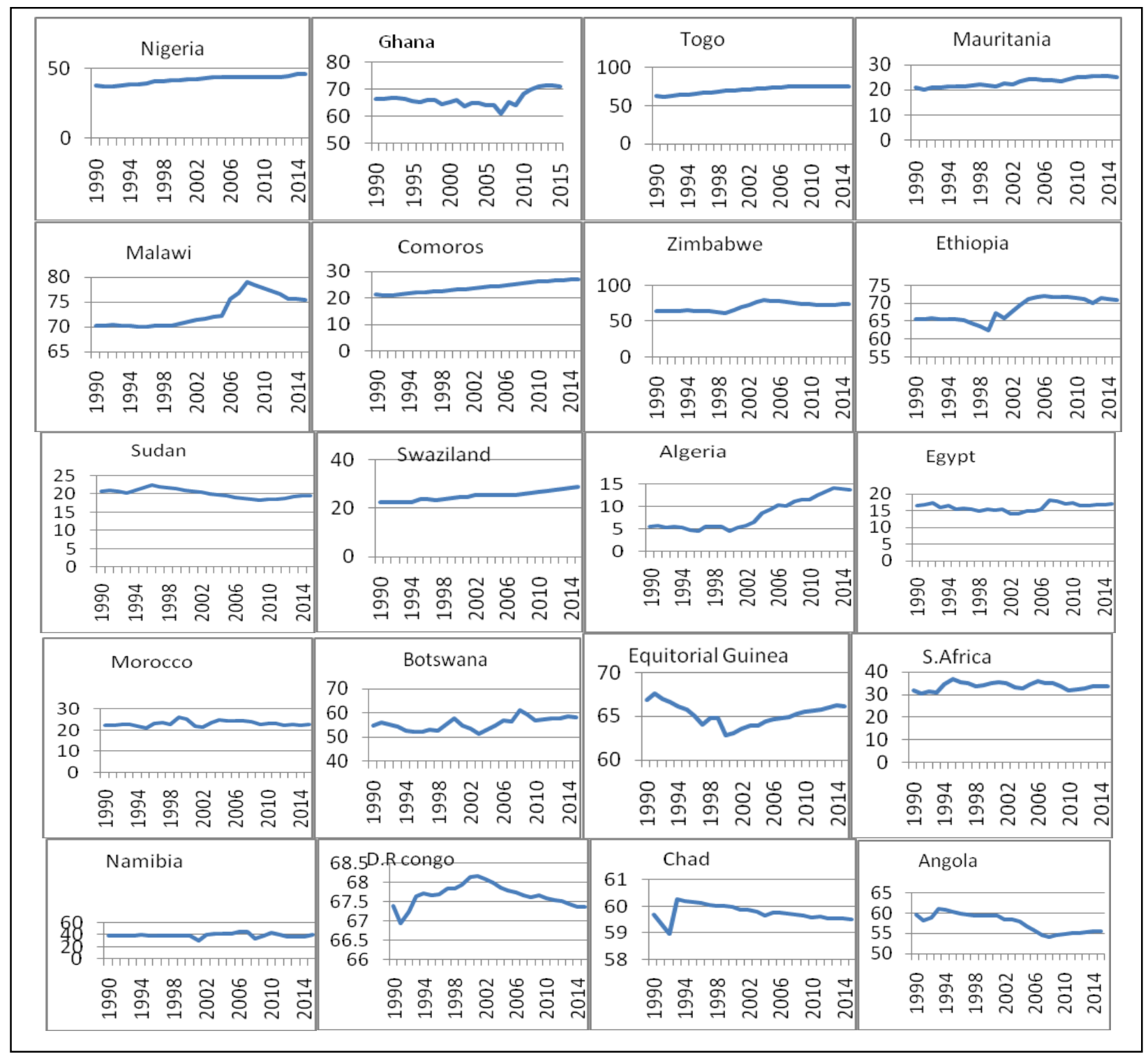

Source: Author's Computation (2019)

In East Africa, though relatively stable, Malawi has been experiencing an upward trend from 70.2 percent in 1990 till 79.1 percent in 2008. The current wave of female economic involvement and the impact of such on growth lead to increase in gender awareness among policy makers and increase in the number of women in decision making positions. In addition to this, is the formulation and execution of gender sensitive policies such as the (i) National Gender Policy (2000)29, which is a short term policy for gender mainstreaming in Malawi (ii) Gender Training Team (GTT) of 1996 by the ministry of women and child development and other measures taken are responsible for the increase female labor demand between these periods (Danish Trade Union Council, 2014)30. Moreover, Zimbabwe has its peak in 2004 with 79.9 percent of female labor demand and it later dropped to 72.8 percent in 2013. This is followed by Ethiopia at its peak year (2006) with 72.0 percent and since then female labor demand has been dropping. Meanwhile Comoros happens to have the lowest female labor demand in the region with less than 30 percent of female labor demand. There are many factors that could be responsible for low female labor demand in 
Comoros, the most important factor is the fact that Comorian society is influenced culturally by Arabian Islam and women are limited to functioning as koranic instruction; Also, the persistent climate of uncertainty which hinders the sustainability of government decisions and efficiency of such on gender mainstreaming in the country and so on (Africa Development Bank, 2009)31. Notwithstanding Malawi still appears to be the country with the highest female labor demand in East Africa.

Algeria followed by Egypt has the lowest female labor demand in Northern Africa with less than 15 percent in Algeria (its peak was 2013 with 14.1 percent), whereas Egypt has less than 20 percent of female participation. This is followed by Sudan while Morocco was found with the highest female labor demand in the region with 24.9 percent in both year 2000 and 2009. The low rate of female employment in Northern Africa region has its roots in religious values and norms. In South African region, Botswana happened to have the highest female labor demand of 61.0 percent in 2008, although unstable but it has been dropping since then. This is followed by Namibia of over 40 percent and South Africa of less than 40 percent of female labor demand. However, Swaziland has the lowest female labor demand of less than 30 percent in South African region.

Central African region has its highest female labor demand of 68.1 percent in Democratic Republic of Congo in the year 2000 and 2001. Equatorial Guinea and Angola have their peak years in 1991 (67.6 percent) and 1993 (60.9 percent) respectively. The lowest female labor demand was found in Chad with 60.2 percent. In all the countries in this region, there has been a slow decrease in female labor demand immediately after their peak years.

It is note-worthy that in all the African countries Zimbabwe and Malawi were found to be the highest female employer of about 79.9 percent and 79.1 percent respectively. While the lowest female labor demand was found in Algeria (Northern Africa) with 14.1 percentage of female population.

\subsection{RESULT OF PANEL UNIT ROOT TESTS}

The result of the stationary tests conducted on all the data by means of heterogeneous panel unit root test (Im, Perasan and Shin (IPS) and Augumented-dickey fuller test) and homogenous panel unit root test (Levin, Lin and Chin) are presented in Table 1. A time series is stated as non stationary if the mean and variance of the time series are dependent over time (Gujarati, 2004)32. On the other hand, a time series is stationary if the mean and variance is constant over time.

However, most economic time series are non stationary and only attain stationary at the first difference level or at a higher level. It is quite important to determine the order of integration before embarking on panel co-integration test. This is as a result of the fact that a non-stationary series contains unit roots and such series has the tendency of sustaining shocks.

Table 1. Panel unit test

\begin{tabular}{|c|c|c|c|c|c|c|}
\hline Variables & $\begin{array}{c}\text { Heterogenous } \\
\text { root }\end{array}$ & Prob. & $\begin{array}{c}\text { Homogenous } \\
\text { root }\end{array}$ & Prob. & $\begin{array}{c}\text { Order of } \\
\text { Integration }\end{array}$ & \\
\hline IPS & ADF-Fisher & & Levin, Lin \& Chin & & \\
\hline DFLFP & -16.451 & 469.964 & $0.000^{* * *}$ & -17.565 & $0.000^{* * *}$ & $\mathrm{I}(1)$ \\
\hline CE & -5.984 & 135.054 & $0.000^{* * *}$ & -4.827 & $0.000^{* * *}$ & $\mathrm{I}(0)$ \\
\hline GDPgr & -10.594 & 175.509 & $0.000^{* * *}$ & -9.204 & $0.000^{* * *}$ & $\mathrm{I}(0)$ \\
\hline GDP/p & -12.232 & 211.259 & $0.000^{* * *}$ & -12.2 & $0.000^{* * *}$ & $\mathrm{I}(0)$ \\
\hline FMLP & -16.281 & 277.323 & $0.000^{* * *}$ & -15.630 & $0.000^{* * *}$ & $\mathrm{I}(0)$ \\
\hline GRLP & -5.476 & 113.823 & $0.000^{* * *}$ & -3.609 & $0.000^{* * *}$ & $\mathrm{I}(1)$ \\
\hline LEB & -9.467 & 407.514 & $0.000^{* * *}$ & -4.099 & $0.000^{* * *}$ & $\mathrm{I}(1)$ \\
\hline
\end{tabular}

Source: Author's Compilation (2019) 
In Table 1, the panel unit root test for demand for female labor force participation shows that at $1 \%$ level of significance, Compensation of Employees (CE), GDP growth rates (GDPgr), GDP per capita (GDP/p), Female Marginal Labor Productivity (FMLP) are stationary at their levels. While Demand for female labor (DFLFP), Gender Ratio in Labor Participation (GRLP) and Life Expectancy at Birth (LEB) are stationary in their first difference.

The stationary status of the variables in the model thus suggests that the Mean Group (MG) / Pooled Mean Group (PMG) and Dynamic Fixed Effect Autoregressive Distributed Lag (ARDL) can be employed or used to carry out the analysis. Hence, the ARDL procedure of MG, PMG and DFE is adopted for the study.

\subsection{ANALYSIS OF DEMAND FOR FEMALE LABOR FORCE PARTICIPATION}

The results of pooled ordinary least square estimation, (PE), fixed effect estimation (FE) and random effect (RE) are presented in Table 2. The result of the Hausman test allowed for the selection of fixed effect regression model. Since fixed effect regression is selected, in order to solve heteroscedasticity problem, robust fixed effect within regression is conducted while standard error was adjusted for 20 clusters in country.

Table 2. Static analysis of demand for female labor force participation

\begin{tabular}{|c|c|c|c|c|c|c|c|c|}
\hline & \multicolumn{2}{|c|}{$\mathrm{PE}$} & \multicolumn{2}{|c|}{$\mathrm{FE}$} & \multicolumn{2}{|c|}{ RE } & \multicolumn{2}{|c|}{ Robust FE } \\
\hline Dflfp & Coef. & Prob. & Coef. & Prob. & Coef. & Prob. & Coef. & Prob. \\
\hline Gdpgr & 0.070 & 0.413 & 0.047 & 0.578 & 0.070 & 0.413 & 0.047 & 0.305 \\
\hline $\mathrm{Ce}$ & -0.012 & 0.368 & -0.011 & 0.383 & -0.012 & 0.368 & -0.011 & 0.585 \\
\hline Fmlp & 4.056 & 0.141 & 4.116 & 0.128 & 4.056 & 0.141 & 4.116 & $0.005 * *$ \\
\hline Gdpp & -0.084 & 0.342 & -0.060 & 0.488 & -0.084 & 0.342 & -0.060 & 0.214 \\
\hline Grlp & 0.494 & $0.000 * * *$ & 0.468 & $0.000 * * *$ & 0.494 & $0.000 * * *$ & 0.468 & $0.000 * * *$ \\
\hline Leb & 0.077 & $0.000 * * *$ & 0.086 & $0.000 * * *$ & 0.076 & $0.000 * * *$ & 0.086 & 0.204 \\
\hline Constant & 8.035 & 0.001 & 9.299 & 0.000 & 8.035 & 0.001 & 9.299 & 0.101 \\
\hline Sigma-u & \multicolumn{2}{|c|}{7.902} & \multicolumn{2}{|c|}{11.861} & \multicolumn{2}{|c|}{7.902} & \multicolumn{2}{|c|}{11.861} \\
\hline Sigma-e & \multicolumn{2}{|c|}{1.786} & \multicolumn{2}{|c|}{1.786} & \multicolumn{2}{|c|}{1.786} & \multicolumn{2}{|c|}{1.786} \\
\hline Rho & \multicolumn{2}{|c|}{0.951} & \multicolumn{2}{|c|}{0.978} & \multicolumn{2}{|c|}{0.951} & \multicolumn{2}{|c|}{0.978} \\
\hline
\end{tabular}

Source: Author's Computation (2019)

Note: ${ }^{* *},{ }^{* *},{ }^{*}$ indicate significance @ $1 \%, 5 \%$ and $10 \%$ respectively

Results from robust fixed effect regression in Table 2 indicates that the overall coefficient of determination (R2) shows that about 87 percent of variation in demand for female labor participation in selected African countries are explained by the variables in the equation.

The result also showed that female marginal labor productivity and gender ratio in labor participation have a significant positive impact on demand for female labor in selected African countries. A unit increase in female marginal productivity increase demand for female by 4.116 units. While a unit increase in gender inequality in employment proxied by gender ratio in labor participation is expected to increase demand for female labor by 0.468 units in selected African countries.

Since, the number of time series and cross sections in this study is 26 and 20 respectively (that is, $\mathrm{T}=26$ and $\mathrm{N}=20$ ), hence they are of the same magnitude. This study made used of Mean Group, Pooled Mean Group and Dynamic Fixed Effect instead of generalized method of moment 
estimators to analyse the dynamic relationship that exist among the variables in the model. This is done to avoid asymptotic imprecision and biases that may arise if GMM is used.

As earlier stated the Mean Group (MG) estimates are the unweighted mean of the individual regressions in each country. While the Pooled Mean Group (PMG) estimator estimates a common long run coefficient and different short run coefficient.

For comparison, Table 3 presents the regression results of MG and PMG estimation for the model.

Table 3. dynamic analysis of demand for female labor force participation

\begin{tabular}{|c|c|c|c|c|c|c|c|c|}
\hline & \multicolumn{4}{|c|}{ MG } & \multicolumn{4}{|c|}{ PMG } \\
\hline & \multicolumn{2}{|c|}{ LR } & \multicolumn{2}{|c|}{ SR } & \multicolumn{2}{|c|}{ LR } & \multicolumn{2}{|c|}{ SR } \\
\hline Dflfp & Coef. & p-value & Coef. & $\mathrm{p}$-value & Coef. & $\mathrm{p}$-value & Coef. & $\mathrm{p}$-value \\
\hline Gdpgr & -32.478 & 0.344 & & & 1.828 & $0.081^{\star}$ & & \\
\hline $\mathrm{Ce}$ & 0.303 & 0.324 & & & 0.680 & $0.048^{\star \star}$ & & \\
\hline Fmlp & 288.512 & 0.341 & & & 2650.086 & $0.000^{\star * *}$ & & \\
\hline Gdpp & 32.748 & 0.341 & & & -1.893 & $0.082^{*}$ & & \\
\hline Grlp & -4.543 & 0.361 & & & 0.616 & $0.044^{\star \star}$ & & \\
\hline Leb & 2.593 & 0.239 & & & 2.203 & $0.000^{* * *}$ & & \\
\hline ECT & & & -0.668 & $0.000^{* * *}$ & & & -0.008 & 0.226 \\
\hline D1.gdpgr & & & 3.442 & 0.062 & & & -0.284 & 0.640 \\
\hline D1.ce & & & -0.038 & 0.423 & & & -0.008 & 0.509 \\
\hline D1.fmlp & & & 0.951 & 0.805 & & & -6.031 & 0.549 \\
\hline D1.gdpp & & & -3.560 & $0.059^{*}$ & & & 0.301 & 0.629 \\
\hline D1.grlp & & & 0.024 & 0.899 & & & 0.701 & $0.000^{* * *}$ \\
\hline D1.leb & & & -0.195 & 0.760 & & & 0.399 & 0.110 \\
\hline Constant & & & -7.976 & 0.455 & & & -1.675 & 0.086 \\
\hline Hausman test & & $\begin{array}{r}\mathrm{H}_{0}: \beta \mathrm{m} \\
0.9\end{array}$ & $\beta p m g$ & & & Faile & ject $\mathrm{H}_{0}$ & \\
\hline
\end{tabular}

Source: Author's Computation (2019)

Note: ${ }^{\star *},{ }^{* *},{ }^{\star}$ indicate significance @ $1 \%, 5 \%$ and $10 \%$ respectively

The constraint of common long run coefficient from MG yielded higher standard errors and speed of adjustment. This is expected since MG is less restrictive, and thus potentially inefficient. In testing the hypothesis of slope homogeneity, we use Hausman (1978) test. The P-values of the Hausman test for PMG and MG is greater than 0.05 (0.9021) and hence does not reject the long run homogeneity restriction hypothesis. Thus, preference is given to pooled Mean Group estimator as this is found to be consistent and efficient under long run slope homogeneity.

In Table 4, the Pooled Mean Group (PMG) estimator is also compared with Dynamic Fixed Effect (DFE) estimator, and Hausman test is applied to test the difference. The P-values of the Hausman test for PMG and DFE is greater than 0.05 (0.9006), this showed the acceptance of null hypothesis. And hence, preference is given to Dynamic Fixed Effect estimator as the efficient estimator. The rejection of PMG indicates the influence of individual specific effect (i.e country), which DFE controlled by imposing homogeneity of all slopes and allowing intercept to vary across countries. 
Table 4. Pooled mean group and dynamic fixed effect estimation results of demand for female labor

\begin{tabular}{|c|c|c|c|c|c|c|c|c|}
\hline \multirow[b]{3}{*}{ Dflfp } & \multicolumn{4}{|c|}{ PMG } & \multicolumn{4}{|c|}{ DFE } \\
\hline & \multicolumn{2}{|c|}{ LR } & \multicolumn{2}{|c|}{ SR } & \multicolumn{2}{|c|}{ LR } & \multicolumn{2}{|c|}{ SR } \\
\hline & Coef. & $\mathrm{p}$-value & Coef. & $\mathrm{p}$-value & Coef. & $\mathrm{p}$-value & Coef. & $\mathrm{p}$-value \\
\hline Gdpgr & 1.828 & $0.081^{*}$ & & & 0.173 & 0.595 & & \\
\hline $\mathrm{Ce}$ & 0.680 & $0.048^{\star \star}$ & & & -0.004 & 0.929 & & \\
\hline Fmlp & 2650.086 & $0.000^{* * *}$ & & & 125.176 & $0.000^{* * *}$ & & \\
\hline Gdpp & -1.893 & $0.082^{*}$ & & & -0.199 & 0.552 & & \\
\hline Grlp & 0.616 & $0.044^{\star *}$ & & & 0.552 & $0.000^{* * *}$ & & \\
\hline Leb & 2.203 & $0.000^{* * *}$ & & & -0.020 & 0.793 & & \\
\hline ECT & & & -0.008 & 0.226 & & & -0.174 & $0.000^{* * *}$ \\
\hline D1.gdpgr & & & -0.284 & 0.640 & & & -0.040 & 0.496 \\
\hline D1.ce & & & -0.008 & 0.509 & & & -0.005 & 0.639 \\
\hline D1.fmlp & & & -6.031 & 0.549 & & & -4.737 & $0.003^{* * *}$ \\
\hline D1.gdpp & & & 0.301 & 0.629 & & & 0.040 & 0.502 \\
\hline D1.grlp & & & 0.701 & $0.000^{* * *}$ & & & 0.477 & $0.000^{* * *}$ \\
\hline D1.leb & & & 0.399 & 0.110 & & & 0.043 & 0.628 \\
\hline Constant & & & -1.675 & 0.086 & & & 1.505 & 0.212 \\
\hline $\begin{array}{l}\text { Hausman } \\
\text { test }\end{array}$ & & Failed tc & ject $\mathrm{H}_{0}$ & & & $\begin{array}{r}\mathrm{H}_{0}: \beta \mathrm{pr} \\
0 .\end{array}$ & $=\beta \mathrm{dfe}$ & \\
\hline
\end{tabular}

Based on the findings from DFE estimator in selected African countries, firstly, the long run result shows that GDP growth rate (GDPgr), wages (CE) Household Income (GDPP) and poverty (LEB) are not statistically significant in determining the demand for female labor in selected African countries. Female Marginal Productivity of Labor (FMPL) and Gender Inequality in Employment (GRLP) show predicted sign and are statistically significant at one percent level of significance. The result shows that an increase in female marginal labor productivity and/or gender inequality in employment increase the demand for female labor.

Similarly, in the short run, female marginal labor productivity and gender inequality in employment are found to be significant. However, female marginal labor productivity indicates a negative relationship. The Error Correction Model (ECM) reveals that error correction term is significant, and it shows negative value for all variables. This confirms co-integration relationship according to Engel and Granger (1987)33. In addition, the ECT incorporates the long run information and shows that any deviation from long run expected values is adjusted by 17.4 percent annually. 


\section{RESULTS}

The results obtained in this study are quite imperative and have far reaching implications for empirical and policy making. Under static and dynamic analysis of demand for female labor, it was discovered that among all stated factors that could affect a country' demand for its female labor, only female marginal labor productivity and gender inequality were found to be significant for the period under study (1990-2015). The result showed that female marginal labor productivity is negative in the short run and positive in the long run, indicating the presence of diminishing return and the presence of economies of scale respectively. It means that with a fixed capital stock, a unit increase in female labor demand will lead to increasing cost and diminishing return in the short run while in the long run the Africa economy will experience economies of scale through increase in size and output. This conforms to the study of Rotaru (2013)34 who discovered a negative relationship between labor marginal productivity and demand in Romania. Moreover, economies of scale in the long run are the cost advantages that an enterprise/economy obtains due to increase in size, output, or scale of production with cost per unit of output generally decreasing with increasing scale as fixed costs are spread out over more units of output. This corroborates importance of female labor in an economy as emphasized by United Nations (2008), they state that increase in women economic participation creates a multiplier effect on productivity, efficiency and sustained economic growth.

Gender inequality in employment was significantly positive and a strong determinant of a nation's demand for its female labor. A unit increase in female employment discrimination drives nations in Africa to demand more of its female labor in order to bridge the gender gap. An example can be seen in the success of Euro zone's labor market, which was brought about by the encouragement of more women participation in the labor force rather than the conventional market reforms (Ernst and Young, 2011)36. Hence, creating opportunities for women in the economy, particularly in developing economies like Africa, will improve their earning capacity, and serve as a spring board for families to move out of poverty and contribute greatly to the overall economy. Also, Sachs (2009)37 stressed that embracing gender equality through increased women participation in labor market will facilitate growth and raise the overall level of human capital, productivity and wages. According to World Bank (2011)38 women tend to spend most of their income on nutrition, children education, and health, which has a spill-over effect on the nations' economy. Moreover, Klassen and Lamanna (2009)39 found that gender gaps in education and particularly in employment considerably reduce economic growth 


\section{CONCLUSIONS AND POLICY RECOMMENDATIONS}

Leaning on findings from this study, the study concludes that what determines the demand for female labor participation in selected African countries is both pull (female marginal labor productivity) and push factor (gender inequality in employment). Moreover, the demand for female labor participation in Africa has not been encouraging due to the increase in female marginal labor productivity which has negative impact on demand for female labor as a result of lack of expansion and progress in manufacturing industry (diminishing return). Over time as female marginal productivity is accompanied with progress in industries and increase in scale of production resulting to economies of scale, this improves the demand for female labor participation in African countries. Secondly, in bridging the gender inequality in labor participation, African countries demand for more of its female labor. However, for this demand to meet the desired response, adequate support services and provisions that can serve as incentive for female to work outside home must be provided.

Based on the conclusion of the study, government and policy makers should improve efforts in bridging the gender gap in employment by ensuring a gender sensitive policies and removing all forms of institutional barriers to female employment in the economy. Also, African government should also make efforts to improve female productivity through training, literacy and household food security. This may also involve a combination of policies such as freeing up woman, so that they can work outside home, for example through subsidized child care as it is being done in Columbia. Improving female access to credit and easing access to productive resources. Addressing lack of information about women productivity in the workplace and eliminating institutional biases against women. For example, by introducing quotas that favour women or job placement programs that can open up economic opportunities for women, more so that gender equality could lead to higher productivity levels and improved livelihoods.

Shifting of aspiration by exposing young female to role models like women leaders in economic and politics (Revenga and Shetty, 2012) 40 may help to ensure that gender gaps do not persist over time. 


\section{REFERENCES}

[1] Population Reference Bureau, World Population Data Sheet: With a special focus on women's empowerment, (2015)

[2] United Nations, World Population Prospects, key findings and advance tables, Department of Economics and Social Affairs, Population Divisions (2015). Retrieved from https://esa. un.org $>$ publication $>$ files

[3] United Nations, Investing in Women and Girls: International Women's Day 2008, United Nations Backgrounder, 2008. http://www.univienna.org/pdf/factsheets_women_2008_e.pdf.feb 2008

[4] Ernst and Young, Women of Africa, A Powerful Untapped Economic Force for the Continent, 2011, retrieved from http://www.ey.com/Publication/vwLUAssets/Women of Africa/\$FILE/ Women\% 20of\%20Africa\%20final.pdf

[5] World Bank, In Times of Crisis, Women can be Agents of Change: Interview with Otaviano Canuto,Vice President and Head of the Poverty Reduction and Economic Management (PREM) Network," PREM Newsletter: Gender Equality as Smart Economics, Fall 2009.

[6] Sachs, G. Australia's Hidden Resource: The Economic Case for Increasing Female Participation, Research Report, Goldman Sachs JB Were Investment Research, (2009)

[7] Morikawa, Y. The opportunities and challenges for female labor force participation in Morocco, Global Economy and Development (Working Paper 86), Brookings (2015)

[8] Mahapatra, S. Women participation in labor force. New Delhi, Rajat Publications, 2002, 46-54

[9] Klassen, S. and Pieters, J. Push or Pull? Drivers of female Labor Force Participation during India's Economic Boom, IZA Discussion Paper Series, 2012, (N0. 6395). Germany.

[10] Bernal, R., and Cardenas, M. Determinants of labor demand in Colombia: 1976-1996. NBER working paper series, WP10077, 2003. http://www.nber.org/paper/

[11] Plekutowska, A. Determinants of labor demand for immigrants in Poland. University of Bialystok, 2007 https://www.researchgate.net/publication/242251937

[12] Rotaru, P. C. A regional Model for labor demand in Romania, Theoretical and Applied Economics, 8(585), 2013, 7-14

[13] Maleszyk, P. The determinants of labor demand in the Lubelskie Voivodship, Barometer Regionalny, 2014,53-63.

[14] Ibrahim, M. A. The determinants of private sector demand for employment in Egypt: 1990-2007, Advances in Management and Applied Economics, 3(1), 2013, 163-182. ISSN: 1792-7544,1792 5527(online). Sciencepress limited

[15] Nguyen, K. T. Determinants of labor demand in the manufacturing sector: Does firm ownership matter? Crawford School of Public Policy, 2013

[16] Adam, A., and Moutos, T. Industry level labor elasticities across Euro Zone: will there be any gain after the pain of internal devaluation. Economics Analysis and Research Department Special Studies Division, 2014, Working Paper ISSN 11096691

[17] Samuelson, P. A. Tale of Two Macroeconomics, Japan and the World Economy, Elsevier, 15(3), 2003, 361-363

[18] Statistical, Economics and Social Research and Training for Islamic Countries (2007) http:// www.sesrtcic.org/stat_database.php

[19] National Gender Policy, Federal Republic of Nigeria Situation Analysis / Framework. The Federal Ministry of Women Affairs and Social Development, 2009, Abuja.

[20] Danish Trade Union Council, Malawi Labor Market Profile. Danish Trade Union Council for International Development and Co-operation, 2014.

[21] African Development Bank, Gender Profile of the Union of Comoros. Africa Development Fund, Abidjan, Cote D’ Ivoire, 2009

[22] D. N. GUJARATI, Basic Econometric, (4th Ed.) (The McGraw-Hill Companies. NewYork, 2004). 
[23] Engel, R. F., and Granger, C. W. J. Cointegration and error correction: Representation, estimation and testing, Econometrica, 55(2), 1987, 251-276

[24] World Bank, World Development Report 2012: Gender. The World Bank, Washington, DC, 2011. [25] Klasen, S. and Lamanna, F. The impact of gender inequality in education and employment on economic growth: New evidence for a panel of countries, Feminist Economics, 15(3), 2009, 91-132

[26] Revenga, A. and Shetty, S. Empowering women is smart economics, Finance and Development, 49(1), 2012, 40-43 